\title{
MEMOIR
}

\section{FRANK MITCHELL REDINGTON}

Frank Mitchell Redington was born on 10 May 1906 in Leeds, the son of a junior shop assistant. Shortly afterwards the family moved to Liverpool, and Frank attended the Dovedale Road Primary School (1912-18) and the Liverpool Institute (1918-25), where in his last year he was Head Boy. Though in his years at the primary school Frank suffered from a rheumatic heart which led to long absences, his considerable mathematical ability later gained him an Open Scholarship to Magdalene College, Cambridge. Frank enjoyed undergraduate life at Cambridge, both for the mathematics and for the wide-ranging discussions with his contemporaries. He thrived on examinations, and achieved 1 st Class Honours in the Tripos, thus becoming a Wrangler in 1928. Although he loved mathematics an academic career did not appeal and he began to study for the actuarial examinations during his last year at Cambridge. Thereafter he gave unsparingly of his talents to the Prudential, the Insurance Industry and the Actuarial Profession.

Frank joined the Prudential in 1928, when Universities supplied only a minority of the Company's trainees. They were not given privileged treatment, but competed on equal terms with entrants from Schools. Frank gained his Fellowship in 1934, and his development took a normal course until soon after the beginning of the Second World War, when many of his contemporaries had joined the forces. He then became involved in a very wide range of actuarial problems, often of an unusual character. It was a testing time but it enabled him to use his outstanding ability to apply original thought to any problem which faced him. He became a member of the Prudential Management as an Assistant Actuary at the then very early age of 39 . After the War, there was much to be done, and Frank embarked upon a revision of the premium rates for all countries in which the Prudential operated. He introduced a more theoretical approach, including the concept of the increasing funnel of doubt' for non-profit contracts. Overseas business had become more important, and Frank introduced improved methods for assessing the profits from each country.

Frank was appointed Chief Actuary of the Prudential in 1951, and continued in that capacity until his retirement in 1968. He applied great professional expertise in leading his team. The quality of his foresight is evident in several major developments while he was Chief Actuary. Thus he saw that uniform bonus rates in all countries would not in the long run be fair to policyholders and, after the war, he achieved differentiation without reducing bonus rates in any country. He supported the view that non-profit contracts could not in the long run provide a suitable vehicle for pension scheme benefits, and with-profit contracts were introduced in the early 1950s. He saw that the proper steering of the finances of an insurer depended on harmony between actuarial and investment policy, and developed a continuing dialogue with his investment colleagues. In the $1950 \mathrm{~s}$, increases in the income from, and the capital values of, equities and property were so large and so sudden that Frank realized that departure from the traditional reversionary bonus system was necessary in order to provide fair benefits to policyholders. The Prudential became one of two leaders to introduce terminal bonuses long before the practice became general.

Frank was doubly grateful for his years as Chief Actuary. In the first place it was work which he enjoyed, and represented the highest achievement which he had envisaged for himself. Secondly, he was happy that his career did not take him to the further appointment of Chief Executive, regarding himself as unsuited to that position.

The channel for most of Frank's effort for the insurance industry was the Life Offices' Association, of which he was Deputy Chairman (1955) and then Chairman (1956-57). He led the LOA Delegation to India in 1956 to discuss the terms of compensation for foreign insurers following the nationalization of life assurance. This was for him a happy experience because of the understanding shown by the Indian Authorities, in particular their acceptance of the claim for compensation for 'excess assets', which reflected the new business strain inherent in published net premium reserves. Frank's Chairmanship of the LOA covered an active time for the industry. There were major developments in the taxation of immediate annuities on an approximation to their interest content 
and of pensions for the self-employed on bases consistent with those used for employed pension schemes. A third area was the financing of national pension schemes, an area of special interest to him presenting problems both for the industry and the profession. Frank's expertise and authority in this field were used to the benefit of the industry over many years, in particular while he was Chairman of the Joint Committee on National Pensions of the LOA and the Scottish Offices (1963-67). He faced the difficult task of guiding the industry to identify and advocate arrangements likely to represent a broad consensus between political parties and so not be subject to frequent change. There was also the need to ensure that occupational schemes themselves would continue to play a major role.

The profession was particularly close to Frank's heart and has been enriched by his long and distinguished service. Following his Fellowship in 1934 Frank began his work within the operational structure of the Institute in 1937 as a member of the Board of Examiners. He was made its Chairman (1945-48) and was a member of the Lever Committee to review the education and examination arrangements which reported in 1946. He became a member of the Executive Committee of the CMI Bureau in 1950 and was its Chairman (1961-68). He served on Council for many years (1944-49 and 1951-64) and became a Vice-President (1953-56) and President (1958-60).

Frank's services to the Profession have extended far beyond his activities on Council and other Committees. His personal authorship and speeches were a stimulus to actuarial thought for almost 50 years. The manner of their presentation has been a model to actuaries on how to think and how to present their thinking. Pensions, life office valuations and mortality investigations were his particular interests. He ensured that the voice of the profession was heard in the debate on national pensions. The subject formed a main theme of his Presidential Address in which he strongly condemned promising pensions in advance under a pay-as-you-go system, and compounding the offence by speaking of them as 'pensions of right'. The booklet National Pensions: an Appeal to Statesmanship published by the Institute and Faculty in 1959 and circulated widely in influential circles owed much to Frank's inspiration. The enduring validity of his views is shown by the references which Stewart Lyon made to them in his Presidential Address in 1982. His 1952 Paper on the Principles of Life Office Valuation is recognized as a landmark in the development of actuarial thought on the relationship between the assets and liabilities of an office. Such was its impact, that not only was the debate on its principles resumed in the next session by the paper of Bayley and Perks, but the discussion has continued long since. By directing thinking towards emerging costs it has transformed the approach to valuations of pension funds as well as life offices.

Because of the state of his health, Frank retired in 1968, rather earlier than intended. His 'work of pre-eminent importance to the profession' was recognized by the award of an Institute Gold Medal later in that year. He had the misfortune to suffer a stroke shortly after he retired, but his courage enabled him to make a good recovery. Retirement then gave him time to reflect from a little distance on the professional problems he met during his active life, and which remain today. These reflexions resulted in a number of papers and essays which were in the main concerned with life office valuations and bonus systems but his continuing interest in mortality investigations was reflected in the paper "An exploration into patterns of mortality" presented to the Institute in 1969. Frank's contribution to actuarial thought has been immense; it will not be possible to assess its full extent until it can be judged in an historical perspective.

In his retirement Frank's activities ranged widely. He was able to continue to enjoy fell walking in moderation. He kept an interest in economics, and has also pursued mysticism and religion, studying in depth Joan of Arc and the Gospels. His approach has been original, and he has not hesitated to question established wisdom. He has investigated his family genealogy, and has found eighteenth century forebears on the borders of Hertfordshire and Essex.

The recital of a man's achievements falls far short of describing his nature. His published works form part of the picture, but they leave it incomplete. They cannot wholly reflect his character. His outstanding quality was enthusiasm. That quality entered everything he did, and the enthusiasm was infectious because of his friendliness, his sense of humour, and his willingness to share and explain his ideas to others. He did much more than apply his powerful intellect to any problem with which he was involved. He dedicated all his qualities of character to finding the best solution and to gaining acceptance of it. His use of English was enviable, both in communicating his ideas and in persuading others to accept them. 
There was a quality of abundance to Frank's life-so prolific were his new ideas that it was hard to decide which should be pursued immediately and which to leave for another day. He was a good listener, but often with strong views on the best course of action; from these he could be moved only by reasoned argument which after rigorous examination he found acceptable. He never favoured solutions which seemed desirable in the short term, without being satisfied as to their long-term implications. He was considerate to those who worked with him, and always tried to ensure good and fair treatment for them. Those of us who have been associated with Frank Redington in any of his activities are very fortunate. He was a leader whose inspiration brought the best out in others.

In 1938 Frank married Katie Rosenfeld, herself an actuarial student, and there are a son and a daughter of the marriage. When accepting the Institute Gold Medal Frank paid tribute to his wife, describing her as his right arm and said of his family that it was their Gold Medal. Frank had a favourite saying that if a man could not explain his ideas to an intelligent woman then either they were not very important or he did not properly understand them himself. It was a dictum which he continually put to the test.

Frank's life, full of fruitful activity and rich in achievement, ended peacefully at home on 23 May 1984 , at the age of 78 .

R. S. SKERMAN 